\title{
The Jerusalem Temple in Luke-Acts ${ }^{1}$
}

\author{
N H Taylor \\ Research fellow: The University of Zululand
}

\begin{abstract}
Luke-Acts was written during the period after the destruction of the second temple, when, for most Jews, hopes for future restoration were conceived largely in terms of rebuilding the temple and city of Jerusalem and resuming the cultic life associated therewith. Against this background Luke poses an alternative vision, in which the divine presence associated previously with the voós is seen no longer as localised but as dispersed. The Holy Spirit manifested in the life and expansion of the Church transcends and supersedes the notion of sacred space associated with the Zion traditions.
\end{abstract}

\section{INTRODUCTION}

It was for much of the twentieth century a canon of scholarly orthodoxy that Luke is the most gentile of New Testament authors (Conzelmann 1982; Dibelius 1956; Haenchen 1971; Maddox 1982; Sanders 1987; Wilson 1973; 1983). This position is now a more debated issue in scholarship (Brawley 1987; Koet 1989; Tiede 1983), but the author's interest in and commitment to the gentile mission is indisputably central to the narrative of Acts, and the gentile mission is clearly anticipated in the gospel of Luke (2:31-32; 4:25-47; $7: 2-10 ; 11: 29-32)$. Yet the Jerusalem temple features prominently in both volumes of this work. References to the temple can be explained neither in terms of widespread Graeco-Roman interest in oriental cults (Fox 1986:64101; MacMullen 1981) and the particular reputation of the temple of Jerusalem (Josephus, CA 1,198-99; 2,138; Cohen 1987; Schürer 1979:309$14)$, nor simply in terms of the temple being the location of several of the events recorded. The temple may on occasion be incidental to the narrative, or simply a geographical point of reference, but it is nonetheless significant that mention should be made of the it so frequently, and that key episodes located elsewhere in Matthew and Mark should be located in the temple in Luke. This is most conspicuously the case with the eschatological discourse, located on the Mount of Olives in Matthew 24 and Mark 13, but in the temple in Luke 21. The temple also features in the nativity and post-resurrection narratives more prominently than in the other gospels. Allusions are never

\footnotetext{
${ }^{1}$ An earlier version of this paper was presented at the Colloquium Biblicum Lovaniense in July 1998, and a briefer version published as Taylor (1999b).
} 
accompanied by detailed descriptions of the architecture or ritual system which would satisfy the curiosity of antiquarian or eclectically minded readers (cf Pliny, Nat Hist 5). While these factors could indicate that the temple is of marginal significance for Luke, there are nevertheless passages where the temple is integral to the narrative and to his apologetic purpose. References to the temple in Luke-Acts, along with other central and distinctive features of Jewish identity and culture, serve to define the continuing significance of Jewish institutions in the light of the Christian Gospel, and the relationship of the Church to Judaism, and therefore merit particular attention (Brawley 1987:107-32; Juel 1983; Tiede 1983). In this respect at least we need to consider whether Luke-Acts was addressed to a (Diaspora) Jewish as well as a gentile readership.

In the view of most scholars, Luke wrote his Gospel and its sequel, the book of Acts, after the temple in Jerusalem had been destroyed (Conzelmann 1987; C A Evans 1990:2; C F Evans 1990:13-15; Fitzmyer 1981:53-57; Marshall 1978:33-35; Schneider 1980; 1985; Taylor 2003a; contra, Munck 1967; Reicke 1972; Robinson 1976:86-117). It is often assumed on this basis that Luke reinterpreted the traditions he had received concerning Jerusalem and the temple in the light of the events of $70 \mathrm{CE}$. The influence of the events of $70 \mathrm{CE}$ on Lukan composition and redaction is disputed by Dodd, who argues that allusions to Old Testament passages account for the differences between Luke 21 and Mark 13 (1947; cf Bruce 1990:16; Fitzmyer 1985:1255; Tiede 1983:67). Whatever the influence of the destruction of Jerusalem on the transmission of the gospel traditions, Luke wrote at a time when the temple was no longer a functioning institution, but one which nonetheless continued to hold immense conceptual and symbolic value for at least the majority of the Jewish people (Cohen 1989:214-31: Grabbe 1991:537-45, 592-95). During the last quarter of the first century CE there would not have been the resignation to the loss of the temple that became characteristic of most strands within Judaism at a later period (1 Enoch 90,28-29; 4 Ezra 10,25-59; 2 Baruch 32,2-4; 68,5; T Ben 9,2; Josephus, BJ 5,19; cf Goodman 1992; Longenecker 1991:40-157; Nickelsburg 1981:277-309; Schürer 1979). Rather, there would have been a general hope and expectation, at least until the time of Hadrian, that in due time and with changing political fortunes Jerusalem would be restored as a Jewish city and the temple rebuilt, as had been the case after the destruction of Solomon's temple by the Babylonians in 587 BCE. It has been argued that Josephus wrote De Bello Iudaico not merely against this background, but in the hope that he would be able to secure the high priesthood in the restored temple (Chilton 1992:77). If a Jew as well connected to the Roman court as Josephus was at this stage in his career 
could entertain such imminent expectations, then we should expect that those who could only reflect upon the prophetic traditions and pray for the restoration of Jerusalem would expect a less imminent turning away of divine wrath and a redemption perhaps less immediate and less to their personal advantage than that to which Josephus aspired. Nonetheless we should assume that Luke-Acts was written against a background in which the majority of the Jewish people hoped for and expected the restoration of Jerusalem and the temple in the foreseeable, even if distant, future.

The function of the temple in Jewish social, economic, political, and cultic life, and consequently its significance in Jewish thought, during the period up to 70 CE was complex (Dunn 1991:31-35; Grabbe 1991:537-45; E P Sanders 1992:47-72). The temple was, for most Jews, the sole legitimate location of their sacrificial cult, and accordingly a place of pilgrimage particularly at the time of major festivals. The temple was also the principal centre for the exposition and administration of Torah, and a source of authoritative rulings on all matters of Jewish life and belief, however widely these may have been observed or however vehemently disputed, or even quietly ignored (Neusner 1983; Sacchi 2000; Sanders 1992:190-240; Saldarini 1988). In addition, the temple and activities located there formed a large part of the economy of Jerusalem and the surrounding areas (Jeremias 1963:21$27,51-57$ ). Underlying and at the same time being reinforced by these aspects of the temple system was the symbolic significance of the sanctuary for the Jewish people. The Holy of Holies was the symbolic centre of Judaism, and, in some conceptualisations, of the cosmos (Ezk 38, 12; 1 Enoch 26-27; Jubilees 8, 12; cf Smith 1978; 1987). It was also conceived as the earthly residence of God, a notion inextricably linked with that of the election of Israel. However literally or otherwise this was understood, and notwithstanding texts in the tradition which acknowledge the inadequacy of the temple as a place of divine residence, the symbolic significance of the sanctuary as a location of the divine presence is not to be underestimated (cf E P Sanders 1992:51-54) The temple was, in summary, the central institution of religious, political, and cultural identity for the Jewish people. Its destruction therefore precipitated a multi-faceted crisis for the Jewish people, one which went far beyond the disruption of the sacrificial cult. Authority in the exposition of Torah was diffused until reconstructed by the rabbis during a later period (Cohen 1984; Neusner 1983). The notion of the temple as the inviolable earthly residence of God was utterly destroyed (Josephus, BJ 5.219.439; 6.285-86). Those Jews who revered the prophetic traditions would have been able to interpret their experience in terms of previous occasions of divine judgement, and thereby to have derived their hopes of eventual restoration (Grabbe 1991:561-64; 
Longenecker 1991:40-157). Those who rejected the prophets, and whose power had been derived from the economy of the temple, were those who failed to re-establish themselves as a force in Jewish society without the temple, and who ultimately perished (Cohen 1984; Grabbe 1991:463-554, 592-95; Neusner 1983; Saldarini 1988). Early Christian attitudes to the temple, including those reflected in Luke-Acts, must be reconstructed against this background.

Assuming a date during the last quarter of the first century, Luke-Acts must have been written with at least some awareness of the politics of Jewish reconstruction in Palestine, as well as of circumstances in Diaspora Judaism at the time. The prominence of the temple suggests a conscious presentation of a Christian alternative to the Jewish hope and quest for restoration of the sanctuary and its cult, and to temple-oriented notions of divine presence, patterns of worship, and ordering of daily life. Rather than affirming hopes for the restoration of temple and cult, Luke expounds a view of the temple that has been superseded by other manifestations of the divine presence, in the person of Jesus and in the life and expansion of the Church in the power of the Holy Spirit. Before proceeding to develop this point, however, we need to consider whether it is possible to describe a single and coherent lukan position on the temple.

\section{TERMS USED OF THE TEMPLE IN LUKE-ACTS}

Four terms are used of the Jerusalem temple in Luke-Acts. This immediately raises questions as to whether a single portrayal of that institution is to be found in the two volume work. The terms used are ó vaós, tò ípóv, ó oîkos, and ó tomós / o ơ yıs. I shall identify their respective occurrences and consider their specific contexts and significance, before attempting to reach an overall position on the temple in Luke-Acts.

\subsection{Tò ípóv}

The term used most frequently is tò iعpóv, with thirteen occurrences in the Gospel and twenty one in Acts. This term refers to the entire temple complex, including the outer courts. Of the Gospel occurrences, five have Markan parallels:

- $\quad$ 19:45 (Mk 11:11; Mt 21:12): the location of Jesus' attack on the traders. The majority of recent scholars believe that, historically, Jesus was proclaiming judgement and destruction on the temple, and that the popular description "cleansing" is inappropriate (Borg 1984:161-74; Chilton 1992:128-30; Crossan 1991:355-60; E P Sanders 1985:61-76; 
Taylor 1999a; Walker 1996:270-72; pace, Casey 1997; C A Evans 1989). This intention is not expressed in the synoptic accounts, but may indirectly be reflected in John 2:19. The significance of this text, and the notion of the temple as a place of prayer for all nations, will be considered further below:

- $\quad$ 19:47 (Mk 11:18; Mt 21:23): the location of Jesus' teaching;

- $\quad 20: 1$ (Mk 11:27): the location of Jesus' teaching;

- $\quad 21: 5$ (Mk 13:1; Mt 24:1): the location of Jesus' destruction saying, in the narrative frame of the eschatological discourse; in Mark and Matthew the pronouncement is made as Jesus and his disciples leave the temple for the last time;

- $\quad 22: 53$ (Mk 14:49; Mt 26:55): Jesus' reference to having taught in the temple, in the arrest pericope.

There is one occurrence of Tò ípóv with a Matthean parallel, which probably derives from Q (Fitzmyer 1981:507; Marshall 1978:166-67; Robinson \& al 2000:28; Taylor 2001; Tuckett 1992):

- $\quad 4: 9$ (Mt 4:5): the location of the third temptation (second in Matthew), to Jesus to throw himself from the temple pinnacle. Scholars are divided as to whether it is Matthew or Luke who alters the order of temptations in Q, with both Matthean (Catchpole 1993:16; Davies \& Allison 1988:364; Dupont 1968:290; Fitzmyer 1981:507-508; Hoffmann 1969:209; Kloppenborg 1989:20; Marshall 1978:167; Nolland 1989:177; Robinson \& al 2000:22-41; Theissen 1991:207) and Lukan (Donaldson 1985:88-98; C F Evans 1990:256; Grundmann 1971:100; Manson 1957:42-43; Schulz 1972:177; Schürmann 1982:218) orders enjoying support. Reasons can be found to explain either order in terms of the theology of the two evangelists (Taylor 2001), and in the case of Luke this concerns an intention to bring the temptation story to a climax in the temple.

- There are six occurrences of Tò ípóv in Luke without parallel in the synoptic tradition:

- $\quad 2: 27,37$ : the account of the presentation of Jesus (2:22-39), related as compliance with Mosaic law (2:22), is located in Jerusalem (2:22; cf 25, $38)$; the temple is implicitly the place where sacrifices are offered (2:24), and is mentioned incidentally as the place where Jesus and his parents encounter Simeon and Anna, neither of whom is a functionary of the cult; derived from special Lukan material (C F Evans 1990:21011; Fitzmyer 1981:82-85; 419-20); 
- 2:46: the location of the twelve year old Jesus' discussion with the teachers, after his Passover pilgrimage with his parents; Lukan composition or derived from special Lukan material (C F Evans 1990:223; Fitzmyer 1981:435);

- 18:10: the location of the story of the Pharisee and the publican, derived from special Lukan material, or possibly Lukan composition (Fitzmyer 1985:1183-85; Nolland 1993:525-31);

- 21:37-38: the location of Jesus' teaching, deriving from Lukan redaction (C F Evans 1990:764-65; Fitzmyer 1985:1357);

- 24:53: the location of the disciples' worship, at the conclusion of the ascension narrative, deriving from special Lukan material or, possibly, lukan redaction (Fitzmyer 1985:1586-87).

- There are twenty one occurrences of Tò ípóv in Acts:

- $\quad 2: 46$ : the location of the disciples' meeting after their reception of the Holy Spirit, probably redactional but deriving from tradition, signifying a claim to be the true Israel and therefore the rightful custodians of what the temple represented (Conzelmann 1987:24; Haenchen 1971:19396; Roloff 1981:65-66);

- $\quad 3: 1.2,3,8,10$ : the location of Peter's healing the crippled beggar, derived from an unknown source (Barrett 1994:177; Conzelmann 1987:25; Haenchen 1971:201-202);

- $\quad 5: 20,21,25$ : the location of the apostles' preaching, in the context of the persecution narrative; Lukan composition (Roloff 1981:100) or deriving from an unknown source (Conzelmann 1987:41; Haenchen 1971:254-58);

- $\quad 5: 42$ : the location of the apostles' teaching and preaching, at the conclusion of the persecution narrative, presumably redactional (Barrett 1994:299);

- $\quad 21: 26,27,28,29,30$ : the narrative of Paul's arrest and ensuing events, deriving from an unknown source (Barrett 1998:1018; Conzelmann 1987:182; Haenchen 1971:611-14, 617-18). Paul serves notice to offer a purification sacrifice, and after a disturbance he is arrested, and accused of having brought gentiles into the designated area (presumably beyond the soreg barrier prohibiting progress of gentiles into the temple; cf Josephus, BJ 5.193-94; E P Sanders 1992:61,7277). The gates of the temple are, pointedly, closed after Paul has been escorted from there, and it is mentioned in the subsequent narrative only in speeches relating events which had taken place there;

- 22:17-18: reference, in Paul's speech after his arrest, to his having received a theophany in the temple, in which he received his call to 
proclaim the Gospel to the gentiles, Lukan composition or deriving from an unknown source (Barrett 1998:1033; Conzelmann 1987:186; Haenchen 1971:628-31). Brawley argues that the location of Paul's theophany at the axis mundi is significant (1987:137; cf Smith 1987). That his vocation to take the Gospel to the gentiles is located in the holiest shrine of Judaism is at least as significant as the broader history of religions conception. While the conscious or subconscious influence of this idea is not to be disputed, what is important for the Lukan narrative is not the mode of communication between God and Paul, but rather that Paul's vocation to preach the Gospel to gentiles is rooted in his Jewish faith and piety;

- 24:6: in the account of Paul's trial before Felix, deriving from an unknown source (Barrett 1998:1092; Haenchen 1971:656-59), the charge of attempted desecration of the temple repeated;

- 24:12, 18: Paul's denial of misconduct in the designated area, in his speech to Felix;

- 25:8: in his speech before Festus, Paul denies misconduct in the temple, Lukan composition or derived from an unknown source (Barrett 1998:1122; Haenchen 1971:668-70);

- 26:21: Paul's reference to his arrest, in his speech before Agrippa, Lukan composition or derived from an unknown source (Barrett 1998:1144-45; Haenchen 1971:690-94).

Of the occurrences of Tò ípóv in Luke-Acts, the majority undoubtedly refer to the outer court of the temple, but at least Luke 21:5 would seem to include all parts of the temple complex in the description, and Acts 21:28 implies areas to which access was restricted. The sacrificial cult is mentioned explicitly only in the presentation account unique to Luke (2:22-39), in the context of the healing of the cripple by Peter and John (Ac 5:20), and of the events preceding Paul's arrest (Ac 21:26-30).

\section{2 óvaós}

O vaós occurs four times in Luke, and twice in Acts. This term is generally understood to refer specifically to the inner sanctuary rather than the temple complex as a whole. One of the gospel occurrences has a Markan parallel:

- $\quad 23: 45$ (Mk 15:38; Mt 27:51): the account of the rending of the sanctuary curtain at Jesus' death, common to the synoptic passion narratives; Luke differs from Mark and Matthew is relating the rending before rather than after the moment of Jesus' death. 
There are no occurrences of ó voós in what can be identified as $Q$ material. The remaining gospel occurrences are located in a single pericope, and derive from a special Lukan source (C F Evans 1990:137-45; Fitzmyer 1981:309-12):

- $\quad 1: 9,21,22$ : the location of Zechariah's offering incense, and of the vision he received while doing so. This tradition is distinctive in implying a kinship relationship between Jesus and John the Baptist, and that the latter was a priest, even if Luke makes no explicit reference to this. $\mathrm{He}$ or his source is, however, clearly aware that the priesthood in Judaism was hereditary (Lk 1:5; cf $m$ Qid 4:4). He must therefore have been aware of the implication that John inherited Zechariah's priestly status, even if he is silent on this. The fact that John is never depicted functioning as a priest, and is later portrayed operating a ritual system outside the temple, may not be insignificant (cf Webb 1991).

The Acts occurrences of ó vaós are distinctive in that they do not refer exclusively to the Jerusalem temple, and on one occasion the reference is specifically to pagan shrines:

- 17:24: Paul's speech to the Areopagus (17:22-34) in Athens, a Lukan composition (Barrett 1998:825-26), possibly incorporating traditions (Pesch 1986:121). Paul repudiates the notion of God living in earthly sanctuaries. The principle is clearly universal in application, even if there is an implied reference to local shrines in Athens, and would therefore embrace the Jerusalem temple (cf Klauck 2003:81-95);

- $\quad 19: 24$ : in the account of the disturbance at Ephesus, reflecting conflict between aniconic Christian devotions and pagan idolatry, and the economic interests of purveyors of the latter (19:21-40), reference is made to silver shrines to Artemis (Diana), presumably souvenirs for pilgrims and/or cultic objects for domestic use (cf Haenchen 1971:572; Klauck 2003:102-10; MacMullen 1981:42).

The distinctive connotation of ó vaós, that of a divine dwelling place (Michel 1967a), is repudiated by the Lukan Paul. The use of the term, without any disclaimer or qualifier, to refer to portable pagan talismans, as though no different in principle to the temple in Jerusalem, would seem to imply the strongest repudiation of the notion of divine residence in terrestrial sanctuaries. The rending of the sanctuary curtain in the gospel Passion narrative likewise implies a denial of divine presence there, or at least the 
withdrawal thereof at the time of Jesus' death. It may be significant that, whereas Mark and Matthew record the rending of the curtain immediately after Jesus' death, Luke records it immediately before, which may be intended to convey the sense that the divine presence had already departed from the temple before Jesus died. It is notable that, after the appearance of Gabriel to Zechariah, an episode which inaugurates the events of the Gospel which follow, vaós occurs in Luke-Acts only in pericopae where its distinctive sense is refuted. This is a point to which I shall return shortly.

In addition to the occurrences of vaós, we should also note its conspicuous omissions from the Passion Narrative. In Mark 14:58; 15:29,38 (Mt 26:61; 27:40) the accusations concerning the temple brought against Jesus both during the trial and after his crucifixion are expressed using voós. These charges are omitted from the Lukan Passion narrative, but reappear in the context of the account of Stephen's martyrdom (Brown 1994:435-37; C F Evans 1990:835; Marshall 1978:847-48; Taylor 2003b; pace, Wilson 1973:131-32). In Ac 6:13-14 the term used is ó tomós ó ăy be considered shortly.

\section{3 ó O̊̂́kOS}

Oîkos is used three, or possibly four, times to refer to the temple in Luke, and in Acts occurs in the context of Stephen's speech. Two occurrences have markan parallels:

- $\quad$ 6:4 (Mk 2:26; Mt 12:4): In controversy with the Pharisees concerning sabbath observance (6:1-5), Jesus makes reference to David's having commandeered shewbread from the sanctuary at Nob (1 Sm 21:1-9). This pericope implies some relativising of the purity system, and of the distinction between sacred and profane, in relation to the temple and its predecessor, the tabernacle. A similar attitude to the sabbath is indicated. The reference to David could suggest messianic overtones to Jesus' overruling established cultic observances;

- $\quad$ 19:46 (Mk 11:17; Mt 21:13): Jesus' citation of Isa 56:7 in the account of his overturning the tables of the money changers (19:45-46). It is noteworthy that, like Matthew, Luke omits from the citation any reference to the gentiles as those who would come to pray in the temple. It is arguable that this reflects a deliberate denial of this eschatological role for the temple (J T Sanders 1987:34; Taylor 1999a; Walker 1996:63), but the omission may simply reflect the historical situation in which Luke (and Matthew) wrote. The temple was 
no longer standing, and could therefore not function either as a Jewish cult centre or as a place of universal prayer. As Luke did not share in the aspirations of the Jewish people for the restoration of the temple, he could envisage no eschatological or ecumenical role for it.

There are two occurrences, one disputed, of oikos in relation to the temple in what is probably $Q$ material:

- $\quad$ 11:51 (Mt 23:35 voós ): Jesus' reference to the martyrdom of Zechariah, in which Luke is almost certainly closer to the original wording of $Q$, though this is a section which both canonical evangelists have reworked (Fitzmyer 1985:946-54; Kloppenborg 1989:112; Robinson \& al 2000:288; Taylor 2003a:298). Matthew develops the tradition further in identifying the Zechariah murdered in the temple (2 Chr 24:20-22) with the canonical prophet. The same tradition was developed further in the extra-canonical writings, culminating in the identification of the murdered Zechariah with the father of John the Baptist (Protev lakobi 23-24; cf Vitae Prophet 15; 23). Luke, on the other hand, does nothing to clarify the identity of Zechariah, presumably retaining an original reference to the first (Abel) and the last murder perpetrated in the Tanakh;

- $\quad$ 13:35 (Mt 23:38): Jesus' reference to Jerusalem's abandoned house, an allusion to $\mathrm{Jr} 22: 5$. It is generally believed that Matthew, locating this text at the conclusion of Jesus' ministry in the temple, retains it in a position closer to that it occupied in Q (Bultmann 1963:114-15; C F Evans 1990:563; Fitzmyer 1985:1034; Grundmann 1971:287; Marshall 1978:573; Robinson \& al 2000:422; Schneider 1985:309; contra, Crossan 1983:345; cf Hoffmann 1982:172; Jacobson 1992:209-13). The oikos reference is ambiguous, and the allusion to the temple is disputed (Brawley 1987:124; C F Evans 1990:565; Fitzmyer 1985:1033-37; Giblin 1985:42; Weinert 1982). The term clearly has wider and more varied connotations, and a reference to the house of Israel in the sense of the Jewish nation cannot be excluded ( $C F$ Evans 1990:565; Fitzmyer 1985:1036; Nolland 1993:742-43). In the same way the city and people of Jerusalem can be included within the reference (Giblin 1985:42; Marshall 1978:576; Plummer 1901:352; Weinert 1982), though not necessarily to the exclusion of the temple. The close association between temple, city, and nation would seem to argue for an inclusive usage in this text, as in 5 Ezra 1:33-34, where DOMUS VESTRA DESERTA EST is followed by reference to lack of progeny. Given 
that oîkoऽ has a definite architectural as well as a familial denotation (Michel 1967b), it would seem most unlikely that reference to the temple can be excluded entirely from the range of meanings (Baltzer 1965; Schulz 1972:346-60; Taylor 2003a; Walker 1996:61-62). The use of $\dot{u} \mu \hat{\omega} v$ of the temple is, however, unusual, and could be understood as a denial of God's possession, and therefore residence, there (Walker 1996:61-62; cf C F Evans 1990:565). The connotations of


logion refers to the temple, it clearly refers to desolation, and by implication the cessation of the cult and of the authority vested in the custodians and other associates of the sanctuary. The saying would not necessarily have referred originally to destruction in the sense in which this came about in $70 \mathrm{CE}$. Desecration such as effected under Antiochus Epiphanes in $167 \mathrm{BCE}$ and intended by Gaius Caligula in 40 CE (Taylor 1996) could also have been envisaged in the saying. In the canonical context, however, this logion clearly reflects the destruction of $70 \mathrm{CE}$. For Luke the fate of the temple had been sealed in the ministry of Jesus (Nolland 1993:742; contra, Giblin 1985:42). God's presence has been withdrawn from the sanctuary (Baltzer 1965). The institution and those associated with it were no longer under divine protection, but vulnerable to judgement which would be meted out in the future (C A Evans 1990:215; Plummer 1901:352). Despite the lack of verbal parallels, this text could represent a $Q$ logion corresponding to the markan traditions of Jesus' pronouncement of the destruction of the temple (Mk 13:2,14; cf 14:58; 15:27; cf Casey 2002).

In addition to these occurrences the special lukan material includes one possible implied use of oîKOS:

- 2:49: In the pericope of Jesus' discovery by his parents in discourse with teachers in the temple, Jesus states that his parents should have

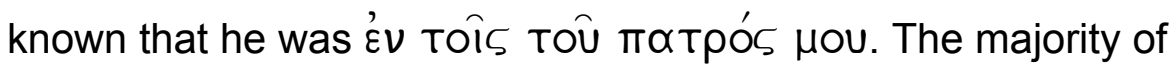
scholars interpret this in a locative sense, as a reference to the temple (cf 2:46; Brown 1993:475-76; C F Evans 1990:226; Fitzmyer 1981:44344; Marshall 1978:129; Nolland 1989:131-32). It is also possible to read the text as stating that Jesus was about his father's business, or with people belonging to his father. While the teachers are not associated with any group hostile to Jesus later in the gospel narrative, they are nonetheless associated with the temple. While depicted positively in 
this pericope, it is unlikely that Luke would regard such persons as distinctively godly or as uniquely meriting Jesus' attention. The preposition ' $\mathrm{V} V$ would be a possible but by no means obvious way of referring to being with people; this construction in this sense is usually found in idiomatic expressions. There is no suggestion that Jesus ought to remain in the temple indefinitely, rather than return to Nazareth. The plural toís would also count against any reference to the temple in this verse. It is therefore most likely that Jesus is referring to his father's business, or commission to him, rather than to the place in which he is located in this pericope.

O oikos referring to a sacred edifice occurs in Acts only in the context of Stephen's speech (7:2-53). Whether the speech is a Lukan composition, or derived from a source, is a matter of scholarly contention (Bihler 1963; Haenchen 1971:270-99; Koester 1989; Richard 1978; Schweizer 1966; Taylor 2003b):

- 7:47: reference to Solomon's having built the temple;

- 7:48: Stephen's repudiation of the notion of earthly sanctuaries as the dwelling place of God, with oikos in the previous verse implied with


universal, the context implies a clear reference to the temple in Jerusalem;

- 7:49: citation of Is 66:1, 2 against the notion of terrestrial divine dwelling places.

The occurrences of o oîkos in reference to the temple are all in contexts of conflict, between Jesus and other Jewish groups or institutions in the Gospel, and between Stephen and his accusers in Acts (Elliott 1991:208). Given that oikos in its literal sense denotes a dwelling place, in a sacral context its connotations are clearly very close to those of vaós. This is confirmed by the usage of both terms in Acts in contexts where the presuppositions of opponents regarding the temple as a place of divine residence are denied. The gospel occurrences, while in contexts of conflict, do not necessarily imply a denial of the notion of a terrestrial divine dwelling place, but the motif of judgement is nonetheless present. 
2.4 ó tomós ó ör

Finally, consideration must be given to a more allusive expression applied to the temple in some contexts in Acts. This is ó tomós ó öy

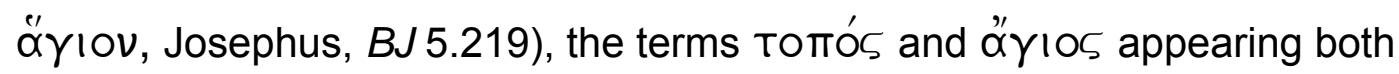
separately and together:

- $\quad 6: 13,14$ : reference to the temple in the accusations brought against Stephen, deriving from an unknown source or other tradition, or redactional (Bihler 1963; Haenchen 1971:270-74; Richard 1978; Schweizer 1966; Taylor 2003b);

- 7:7: a clear reference to the temple by Stephen, although the adjective व̈ $\gamma 105$ is omitted;

- 7:49: citation of Is $66: 1,2$ by Stephen, parallel to oîkos in the preceding line (see discussion above);

- $\quad 21: 28$ (bis): reference to the temple in the charges brought against Paul after his arrest, redactional or deriving from tradition (Barrett 1998:1018).

Given the frequency with which ö $\gamma 105$ occurs in Luke-Acts, referring to the Holy Spirit (Lk 1:15, 35, 41, 67; 2:1, 25, 26; 3:16, 22; 4:1; 12:10, 12; 11:13; Ac $1: 2,5,8,16 ; 2: 4,33,38 ; 4: 8,31 ; 5: 3,32 ; 6: 5 ; 7: 51,55 ; 8: 15,17,19 ; 9: 17,31$; $10: 38,44,45,47 ; 11: 15,16,24 ; 13: 2,4,9,52 ; 15: 8,28 ; 16: 6 ; 19: 2,2,6$; $20: 23,28 ; 21: 11 ; 28: 25)$ and to holy people (Lk 1:35; $4: 34$ [Jesus]; $1: 70$ [prophets]; 2:23 [firstborn, citing Ex 13:2, 12]; 9:26 [angels]; Acts 3:14; 4:27, 30 [Jesus]; $3: 21$ [prophets]; 10:22 [angel]), and to the Covenant (Lk 1:72), it is particularly noteworthy that the temple is never designated as ö $\gamma 105$ except

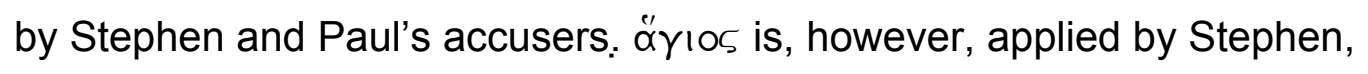
citing Ex 3:5, to the ground on which Moses was standing when he received the theophany in the burning bush at Horeb. Given that this is a quotation from Scripture, a contrast between a holy place in the wilderness and urban cultic institutions should not be unduly emphasised. Moreover, the temple is referred to as "̈ $\gamma 105$ elsewhere in the synoptic tradition only in the Matthean eschatological discourse (24:15; cf Mk 13:14; Lk 21:17). Furthermore, the connotation of holiness is implicit in the other terms used, in particular to iعpóv, so the scarcity of occurrences in Luke-Acts may not be altogether significant. The polemical context of ó torós / ó ăyıs in Acts, however, is not to be discounted. 


\section{A SINGLE CONCEPTION OF THE TEMPLE IN LUKE- ACTS?}

Given that four terms are used of the Jerusalem temple in Luke-Acts, and that Luke is clearly dependent on sources for most references, the question needs to be asked whether we can speak of a single, unified conception and theological position vis-à-vis that institution. The occurrences of vaós all derive from sources rather than from the evangelist, and the same is true of the more allusive, if all but synonymous, term oîkos. It is, furthermore, unlikely that more than one occurrence of ípóv is not derived from sources. Where Luke is drawing on sources, he appears never to change the terminology regarding the temple, assuming that he retains the original wording of $Q$ where Matthew has changed it. If, however, Luke is dependent on Matthew rather than these sources (Farmer 1964; Goulder 1989), then he does make some changes, but these are not of major importance. Therefore it could be argued that, at the redactional level, there is no single conception of the temple in Luke-Acts. However, some patterns are discernible in the use of these terms, which would suggest at the least that sources have been utilised so as to support the theological position of the evangelist. It has been noted that voós occurs after the appearance of Gabriel to Zechariah only in contexts where divine residency in the temple is denied and the notion thereof derided. oikos similarly appears only in contexts where there is conflict with the Jewish establishment, though the status of the temple is not necessarily at issue. ípóv tends to refer in more general terms to the temple precincts rather than specifically to the sanctuary area. While implying a notion of sanctity, ípóv is nonetheless theologically the most neutral of the terms employed by Luke, and perhaps conveys a geographical rather than a theological meaning and significance. While we need to proceed with some caution in drawing conclusions on the basis of Luke's use of terminology, it would nevertheless seem that some significance must be attached to the patterns identified in the use of voós in particular, and also of oîkos.

\section{THE TEMPLE IN THE KEY EPISODES IN THE NARRATIVE OF LUKE-ACTS}

Having identified the words used by Luke for the temple, their sources so far as these can be established, and some aspects of their significance, we need to consider the place of the temple in key episodes in the overall narrative of Luke-Acts. 
- Luke 1:8-22 (voós): the appearance of Gabriel to Zechariah in the temple

As noted above, this is the only pericope in which vaós is used where the notion of divine residency in earthly temples is not repudiated. This suggests that, with the events of the Gospel inaugurated in the appearance of Gabriel to Zechariah, Luke understands the special significance of the temple under the old covenant as having come to an end. The next place of angelic revelation is not the temple, but the home of Mary in Nazareth (1:26-38). In the subsequent narrative John the Baptist is depicted operating outside and effectively in opposition to the temple, possibly in an overtly priestly role (3:1-20; cf Webb 1991).

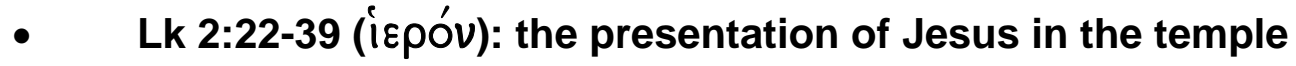
While sacrifices would have been offered on such an occasion, voós is not used. The relevant events concern not the cult, which is alluded to only in passing (2:22-24, 39), but the encounters with the prophets Simeon and Anna. The parents of Jesus are depicted as Torahobservant, but the emphasis in this narrative is on the fulfilment of eschatological expectations derived from the Isaiah tradition as interpreted by Simeon and Anna, in which the former espouses universalist as well as nationalist hopes.

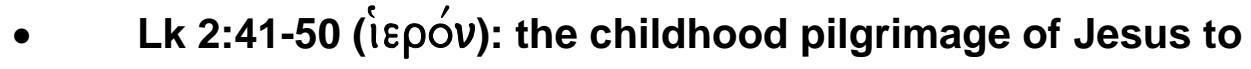
Jerusalem at Passover

This passage is significant in confirming the Torah-observance of Jesus' family. While Passover would have been an occasion for undergoing purity rituals and partaking of the sacrificial lamb, the emphasis is on Jesus' claim to divine sonship, and by implication to as yet undefined jurisdiction over the temple. Christian appropriation of the temple courts as a venue for meeting and proclaiming the Gospel in the early chapters of Acts corresponds with this text.

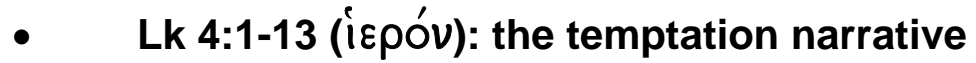

As noted above, scholars debate the original order of the temptations, with the majority arguing that Mt 4:1-11 follows the sequence of $\mathrm{Q}$. In this case, Luke would be indicating a theological purpose in altering the order of the temptations so that the sequence comes to a climax in the temple. In this Luke foreshadows the progress of Jesus towards Jerusalem in the gospel narrative, as his vocation is tested in three 
eschatologically significant locations. Donaldson has drawn particular attention to the progress of the shekinah in Ezek 43:2, as the glory of God returns at the restoration, from the wilderness, via the Mount of Olives, to the temple (1985:97). This would seem further substantiation of the position taken in this study that Luke presents Jesus as the earthly embodiment of shekinah in the gospel, and that in Acts the divine presence is portrayed as dispersed with the spread of the Church (cf Baltzer 1965).

\section{- $\quad$ Lk 13:34-35 (oîKO5): the desolation saying}

As noted above, the allusion to the temple is disputed. It would seem unlikely, however, that there is no reference to the temple in this text, though not to the exclusion of a wider range of meanings. It has been argued that there is no reference to the destruction of Jerusalem in this text, and that the abandonment of Jerusalem consists in being without Jesus' ministry (Giblin 1985:42). Even if " text (cf Robinson \& al 2000:422), however, readers would have discerned the allusion to the events of $70 \mathrm{CE}$, and Luke would have been aware that this inference would have been drawn. It is most unlikely that Luke's original readers would have failed to discern an allusion to this event in this saying. The desolation is not in Luke a consequence of rejection of Jesus himself, which has not yet taken place, but rather the consequence of repeated rejection and persecution of the prophets, in continuity with whose ministry Jesus pronounces judgement (cf Giblin 1985:41). In the prophetic tradition judgement does not necessarily mean inevitable destruction, but the pronouncement thereof aims and hopes rather to evoke repentance (Jer 6:1-8; 21:3-14; 26:2-23; Mic 3:1-12; Zeph 3:1-8; 2 Macc 6:12-17). Nevertheless, Luke was writing in the aftermath of the events of $70 \mathrm{CE}$, and this text could therefore have been interpreted by his original readers only in terms of this judgement having been meted out on Jerusalem, and therefore as having been inevitable were Jerusalem to reject Jesus as it had the prophets before him (Taylor 2003a).

- Lk 19:45-21:38 (ípóv, oîkos): Jesus' attack on the traders, and subsequent teaching and debating with the authorities in the temple court

The emphasis on the temple as a place of prayer (Lk 19:46; 21:10; so also 2:37; 18:9-14; 24:53; Ac 2:46; 3:1; 22:17) and teaching (Lk 19:47; 21:37,38; so also Ac 3:11; 5:19-20,42), with the sacrificial cult 
mentioned rarely (Lk 19:45; cf Ac 2:46; 3:1). Jesus is in frequent conflict with established authority (Lk 19:45-20:8,19-40; so also Ac 4:1$21 ; 5: 17-40$ ), which would seem to emphasise continuity with the prophetic tradition of Israel. Unlike Matthew (21:14), Luke makes no mention of healings by Jesus in the temple. This text includes several pericopae, some of which require separate treatment.

- Lk 19:45-46 (ípóv): Jesus' attack on traders in the temple court This is a much briefer account than in Mk 11:15-17 and Mt 21:12-13, and does not specify the financial transactions taking place. It is notable that the citation of Is $56: 7$ omits the reference to all nations, and that $\mathrm{Jr}$ 7:11 forms part of a prophecy of the destruction of the temple. Arguably the omission of reference to all nations from the quotation from Isaiah can be attributed to Luke's having written after the temple had been destroyed, at a time when this text was incapable of fulfilment. However, if, as has been argued in this paper, Luke wrote against a background of expectation of rebuilding of the temple, then his first readers would not have assumed that (Trito-) Isaiah's prophecy could no longer be fulfilled. Luke's omission of the reference to all nations therefore reflects his own understanding of the temple as having no eschatological role. He does not anticipate any eschatological fulfilment of Isaiah's prophecy of worshippers from all nations gathering in the temple. On the contrary, he opposes any expectation of such fulfilment.

- Lk 21:5-6 (iєpóv): the destruction saying, followed by the eschatological discourse

Whereas in Mk 13:1-2 and Mt 24:1-2 the destruction saying accompanies Jesus' final departure from the temple and the eschatological discourse is delivered from the Mount of Olives, in Luke these events take place within the temple precincts. While the final recorded speech of Jesus in the temple, the eschatological discourse is not intended as the conclusion to his ministry there, as 21:37-38 suggest a continuing if unrecorded teaching ministry in the temple after this discourse. The expectation that the temple would be destroyed is unequivocal, and there is no hint that this could be averted, or that a new temple might be built. 
- $\quad$ Lk 21:20-24: the desolation of Jerusalem

The reference in Mark 13:14 and Mt 24:15 to the desecration of the temple through the installation of an idol is replaced with a more general reference to a siege of Jerusalem. The temple itself is not mentioned, but cannot be separated from the siege and destruction of Jerusalem. Irrespective of whether the differences between Lk 21:2024 and the account in Mark and Matthew can be attributed to Luke's knowledge of the events of 70 CE (Taylor 2003a), it is clear that scriptural allusions to the destruction of 587 BCE are employed (Is 63:18; Dn 8:13; Zch 12:2-3; cf Dodd 1947). While reference is made to captivity and exile of the people, this point is not laboured or embellished with allusions to Titus's carrying the cultic apparatus along with his Jewish captives in triumph to Rome. This, it will be argued below, is to avoid an impression that Rome has become the locus of divine presence in place of Jerusalem. While the concluding phrase

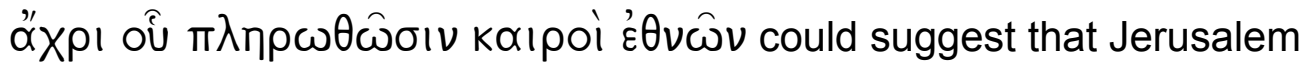
might one day be restored, as a Jewish city, when the time comes for the gentiles to be judged (Brawley 1987:125; C A Evans 1990:313; Marshall 1978:773-74; Nolland 1993:1002-1004), it is also open to interpretation as suggesting that the destruction would be complete (Fitzmyer 1985:1347; J T Sanders 1987:218). As the eschatological discourse proceeds to recount the events immediately antecedent to the parousia (21:25-28), it would seem more likely that any future restoration of Jerusalem and the temple is precluded (cf C F Evans 1990:752). This does not necessarily imply irrevocable judgement on the Jewish people (pace, J T Sanders 1987:218), but rather points to a redemption of cosmic proportions which would not include but would transcend the restoration of Jerusalem and its Jewish temple. For Luke the role of the temple in salvation history has been completed, and the building would therefore not be restored.

- $\quad$ Lk 22:66-71: the trial of Jesus before Caiaphas Unlike Mark (14:58) and Matthew (26:61), Luke makes no reference to any accusations regarding the threatened destruction of the temple. This despite the fact that Luke records Jesus' having pronounced this destruction (13:34-35; 19:43-44; $21: 6)$, and having done so within the temple and in the hearing of the populace. However, in omitting reference to the temple here, Luke is able both to avoid the ambiguities of a false charge and to separate the death of Jesus from the destruction of the temple, as he continues in the crucifixion narrative, to 
be considered below. The accusations surface, in a somewhat mutated form, in the account of the trial of Stephen in Acts (6:14). Luke presents the christological issues as of central importance to the trial of Jesus, rather than the fate of the temple. As noted above, Luke does not link the destruction of Jerusalem directly with Jesus' death, but rather sees the death of Jesus in continuity with those of martyred prophets whose message had been rejected. The judgement aspect of the destruction of the temple is subordinated to Luke's conviction that divine presence is no longer localised there but disseminated in the expansion of the Church.

\section{- $\quad$ Lk 23:26-43: the crucifixion of Jesus}

As with the trial narrative, all reference to Jesus' prophecy of the destruction of the temple is omitted (cf Mt 27:40; Mk 15:29). Even the address to the women of Jerusalem in 23:28-31 makes no explicit reference to the destruction of the city. Luke's separation of the death of Jesus from the destruction of the temple becomes most apparent in the account of his death.

\section{- $\quad$ Lk 23:44-46 (v@ós): the death of Jesus}

The rending of the sanctuary curtain is reported before Jesus' death, rather than after as in Mk 15:38 and Mt 27:51. The significance of this event is debated in scholarship. It has been argued that the curtain is torn to open communication between Jesus and God, just as Stephen was to see heaven opened before his death in Ac 7:56 (Sylva 1987). The rending of the curtain, however, should not be separated from the other recorded portent, that of darkness, which is clearly ominous. In Vit Proph 12 the rending of the curtain is also an eschatological portent (cf Brown 1994:1135-1136). There is no indication that Jesus' dying words are addressed to a God located in the opened and exposed sanctuary. Rather, the torn curtain reveals the emptiness of the voós, and in placing the exposure of the sanctuary prior to Jesus' death Luke indicates that it had already ceased to be a place where the divine presence was localised and concealed. The departure of the shekinah from the temple is not a consequence of Jesus' death, and is therefore not in itself an act of judgement. Rather, the emptiness of the sanctuary reveals that the temple had already completed its purpose, and the divine presence was already manifested elsewhere, in the person of Jesus. 


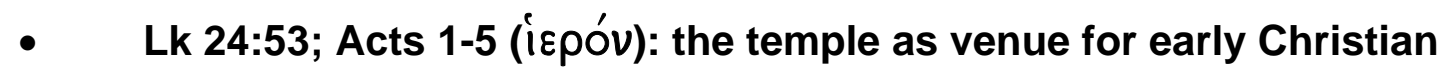
worship and teaching

The indications that early Christian worship in Jerusalem may have on some occasions been synchronised with the sacrificial routine of the temple (Ac 3:1) is potentially significant, even if this is purely Lukan supposition. However, there is no suggestion of Christians participating directly in the cult until Ac 21:23-24, 26-27 when Paul and others underwent a purification ritual. While the Christians are portrayed as not having ceased to regard the temple as a place of prayer, and they are depicted as continuing Jesus' practice of using the precincts as a place of teaching, this does not mean they regarded the temple in the same light as did other Jews (cf Taylor 1999a; Walker 1996:297-99). Rather, they claim Jesus' jurisdiction over the temple in using its premises for their own activities. Luke has not linked the destruction of the temple to the death of Jesus, nor has he separated the temple from the city and people of Jerusalem in his pronouncements of judgement. Christians in Jerusalem are therefore under no obligation to anticipate the destruction of the temple in their worship or in their teaching. This does not mean that the apostles had forgotten Jesus' proclamation of the destruction of the temple, but simply that they began to preach the Gospel in the same place as that in which Jesus had ended his public ministry.

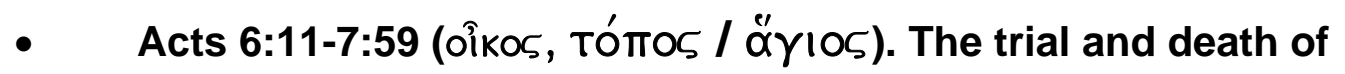
Stephen

A large number of critical issues surround this text (cf Bihler 1963; Kilgallen 1974; Richard 1978; Scharlemann 1968; Taylor 2003b). It is not necessary for the present purpose to rehearse all the debates surrounding the composition of the narrative and its historical background (cf Cullmann 1975; Dunn 1991:57-74; Hengel 1983:1-29; Scharlemann 1968; Simon 1958; Trocmé 1973). There is some consensus that Luke has embedded a trial narrative, including Stephen's speech, into a more original account of Stephen's having been murdered by a lynch mob. It is noteworthy that Stephen does not repeat or explicitly refute the charges on which he is arraigned in the narrative frame. He is at the very least critical of some conceptions of the temple (Dunn 1991:63-67; Taylor 2003b; pace, Brawley 1987:12123; Hill 1992:67-101), although there is debate as to what precisely the thrust of his critique is. While some scholars draw attention to a dichotomy between the tabernacle in the wilderness and the temple in 
Jerusalem (Koester 1989; Simon 1951), the notion of divine residence in earthly structures which Stephen attacks in 7:48 would apply to both, except in that the temple is immobile and significance is therefore attached to its site as well as its buildings (cf Smith 1978; 1987; Brawley 1987:127-132). In this respect Stephen stands in continuity with the prophetic tradition, as reflected both in the Deuteronomistic History and in the classical Prophets (1 Ki 8:27; Is 66:1-2). Irrespective of whether divine residence was conceptualised in literal terms (cf E P Sanders 1992:51-54), any challenge to the notion would have been offensive to those who believed the temple to have been built on a uniquely sacred site, and to those whose economic and political power were derived from the temple and its cult. Shiloh, the traditional final resting place of the tabernacle, had been destroyed, as had the temple built by Solomon; the destruction of the former being cited by Jeremiah in warning of the destruction of the latter (Jr 7:12-15; 26:4-9; cf Ps 78:60). This in principle leaves Herod's temple vulnerable to divine judgement and destruction, although Stephen makes no mention of the destruction of previous edifices which had been regarded as divine dwelling places (cf Kilgallen 1976). Stephen's speech cannot be understood as a refutation of the charge that he had claimed that Jesus would destroy the temple, and would be consistent with an implied affirmation that the temple would be destroyed (Taylor 2003b). Given that the reader is in no doubt that Jesus had proclaimed the destruction of the temple, there can be little doubt that Stephen's speech, if not a denunciation of the temple, at the very least rejects the notion of the temple as a divine residence and prepares for Luke's account of the dissemination of the divine presence with the spread of the Church which follows Stephen's death (cf Baltzer 1965; Koester 1989:98; Scharlemann 1968).

\section{THE TEMPLE AND THEOLOGICAL MOTIFS IN LUKE- ACTS}

Before reaching any conclusions on the significance of the temple in LukeActs, it would be useful to consider it in the context of other theological motifs found in the Gospel and the Lukan account of the early Church. The most important of these, perhaps, are divine providence, the manifestation and inspiration of the Holy Spirit and the spread of the Church from Jerusalem to Rome, including gentiles as well as Jews in the process (Conzelmann 1982; O'Toole 1984; Squires 1993; Tiede 1983). Rome, however, does not inherit the position forfeited by Jerusalem, and it is arguable that the line of 
geographical expansion chosen by Luke is influenced more by his interest in Paul than by any theological significance attached to Rome (Brawley 1987:2850). While Luke focuses on one direction in the spread of Christianity, there is no suggestion that the imperial city becomes the centre of the Church. It is perhaps significant that, by the time Luke wrote the Gospel and Acts, Titus had destroyed Jerusalem and taken such treasures and apparatus of the temple as could be salvaged from the flames to Rome in triumph (Josephus, BJ 7.148-52). Luke makes no allusion to this, and does not exploit the conveying of cultic apparatus from Jerusalem to Rome to support any theme of Acts. While the narrative ends some years before these events (cf Jewett 1979; Knox 1954; Taylor 1992), they would nonetheless have been known to the first readers of the work. Had Luke wished to intimate that Rome had inherited the centrality and symbolic significance of Jerusalem, he could have worked some allusion to the triumph of Titus into his gospel eschatological discourse, and drawn on motifs from the closing chapters of the Deuteronomic History and the prophetic corpus in doing so (cf Brandon 1961). However, I would suggest that this is an impression Luke consciously and quite deliberately avoids. The narrative includes two quite emphatic denials of the notion of localised divine presence, delivered by Stephen and Paul, before the latter reaches Rome (Ac 7:48; 17:24). While the narrative of Acts implicitly recognises Rome as the centre of the empire, and of the world in which the first Christians lived, the notion of divine presence is expressed not in terms of residency and centrality, but in the Holy Spirit manifest in the life and growth of the Church. The spread of the Church is not conceived as having been in one direction only, Luke's interest in the more general expansion of Christianity can be illustrated from the diversity of witnesses at Pentecost (Ac 2:8-11) and the encounter between Philip and the Ethiopian official (Ac 8:2640 ), even if the narrative focuses predominantly on the route from Jerusalem to Rome. A sacred site as the definitive place of communication between humanity and God has become redundant with the ministry of Jesus (cf Brawley 1987:119-20; Baltzer 1965). Localisation of the divine presence in the narrative of Luke-Acts effectively ends with the appearance of Gabriel to Zechariah at the commencement (Lk 1:8-22), and the negation or termination of divine presence is confirmed through the rending of the sanctuary curtain, exposing the emptiness of the voós, at the crucifixion of Jesus, but before his death (Lk 23:45). The ending of the localisation of the divine presence in the sanctuary with the coming of John the Baptist may be reinforced by his not following his father in temple service. Rather, John functions outside the official cult, offering teaching and a ritual system which can in at least some ways be understood as an alternative to the temple cult (Lk 3:1-20; cf 
Hollenbach 1979; Horsley \& Hanson 1987:176-81; Kraeling 1951; Scobie 1964; Webb 1991). Furthermore, John's role is explicitly associated in LukeActs with preparation for the coming of Jesus and the manifestation of the Holy Spirit in the Church (Lk 3:16; Ac 1:5, 22; 10:37; 11:16; 13:24, 25; 19:4). Thereafter, both the appearances of the resurrected Jesus in Luke 24 and the empowerment by the Holy Spirit of the followers of Jesus in Acts 2 manifest the dissemination of the divine presence (Baltzer 1965). With the coming of John the Baptist the temple ceases to function as the locus of divine presence on earth. Jesus becomes the primary manifestation of divine presence during his ministry, but the status of the temple as divine residence is not refuted until the moment of Jesus' death. However, it is noteworthy that, whereas Matthew and Mark record the rending of the veil immediately after the death of Jesus (Mt 27:50-51; Mk 15:37-38), in Luke it precedes Jesus' death. For Luke the status of the temple as divine residence has already ended with the commencement of the Gospel, and is not brought about by the death of Jesus.

\section{CONCLUSION}

In conclusion, therefore, I wish to argue that Luke's presentation of the temple is to be located in the context of Jewish and Christian reconstruction during the period after the Roman-Jewish war of 66-70 CE. Particularly through his use of voós, Luke suggests that the divine presence traditionally associated with the sanctuary of the temple is no longer localised in Jerusalem, or for that matter in any other sanctuary. The shekinah had ceased to be located exclusively in the temple with the beginning of the Gospel, and the Jewish sanctuary had accordingly ceased to fulfil its function long before its destruction; it had been exposed as an empty shell at the death of Jesus. In Acts, divine presence has come to be manifested in and through the Holy Spirit in the life of the Church. The fall of Jerusalem and destruction of the temple do not represent the triumph of paganism and the Roman gods, but simply confirms that the temple is no longer the locus of divine presence. The restoration of God's presence among the Jewish people is therefore to be sought not through aspiring to rebuild the temple in Jerusalem, but in conversion to the Christian gospel and receiving baptism and the empowerment of the Holy Spirit, and participating in the dissemination of the Gospel and spread of divine presence throughout the world.

If this hypothesis is correct, it would have implications for what has become a canon of scholarly consensus that Luke-Acts is addressed primarily to Gentiles. Even if the author has a primarily gentile readership in mind, he is deeply concerned with the issue of the continuing validity of Jewish 
institutions, and, by implication at least, posits a path to salvation for the Jewish people apart from the temple and its cult. Luke is undoubtedly concerned that gentile Christians should recognise their path to salvation as lying outside the boundaries of Judaism, even if deriving therefrom, and may for that reason wish to reassure them that the destruction of the temple had no implications for them. However, the possibility needs to be considered that Luke may wish to offer to Jewish readers a sense that the temple had lost its significance before it had been destroyed, and that a new path to salvation had already been established in Christ. Rather than seek the restoration of Jerusalem, Jewish readers of Luke-Acts should embrace the diffusion of divine presence throughout the gentile world in the life and mission of the Christian Church.

\section{Works Consulted:}

Baltzer, K 1965. The meaning of the temple in the Lukan writings. HTR 58, 263-77. Barrett, C K 1994-1998. The acts of the apostles. Edinburgh: Clark. Bihler, J 1963. Die Stephanusgeschichte. München: Hüber.

Borg, M J 1984. Conflict, holiness and politics in the teaching of Jesus. New York: Mellen.

Brandon, S G F 1961. The date of the Markan gospel. NTS 7, 126-41.

Brawley, R L 1987. Luke-Acts and the Jews. Atlanta, GA: Scholars.

Brown, R E 1993. The birth of the Messiah. New York: Doubleday.

Brown, R E 1994. The death of the Messiah. New York: Doubleday.

Bruce, F F 1990. The Acts of the Apostles. Grand Rapids, MI: Eerdmans.

Bultmann, R K 1963. History of the synoptic tradition. Oxford: Blackwell.

Casey, P M 1997. Culture and historicity: the cleansing of the temple. CBQ 59, 30632.

Catchpole, D R 1993. The quest for Q. Edinburgh: T\&T Clark.

Chilton, B D 1992. The temple of Jesus. University Park, PA: University of Pennsylvania Press.

Cohen, S J D 1984. The significance of Yavneh. HUCA 55, 27-53.

Cohen, S J D 1987. Respect for Judaism by gentiles in the writings of Josephus. HTR 80, 409-30.

Cohen, S J D 1989. From the Maccabees to the Mishnah. Philadelphia, PA: Fortress.

Conzelmann, H G 1982. The theology of Saint Luke. London: SCM.

Conzelmann, H G 1987. Acts of the Apostles. Philadelphia, PA: Fortress.

Crossan, J D 1983. In fragments. San Francisco, CA: Harper.

Crossan, J D 1991. The historical Jesus. San Francisco, CA: Harper.

Cullmann, O 1975. Von Jesus zum Stephanuskreis und zum Johannesevangelium, in Ellis, E E \& Grässer, E (ed), Jesus und Paulus, 44-56. Göttingen: Vandenhoeck \& Ruprecht.

Davies, W D \& Allison, D C 1988-1997. The Gospel according to Saint Matthew. Edinburgh: T\&T Clark.

Dibelius, M F 1956. Studies in the Acts of the Apostles. London: SCM. 
Dodd, $\mathrm{CH}$ 1947. The fall of Jerusalem and the abomination of desolation. JRS 37 , 47-54.

Donaldson, T L 1985. Jesus on the mountain. Sheffield: Sheffield Academic Press.

Dunn, J D G 1991. The partings of the ways. London: SCM.

Dupont, J 1968. Les tentations Jésu au desert. Brugge: Brouwer.

Elliott, J H 1991. Temple versus Household in Luke-Acts, in Neyrey, J H (ed), The social world of Luke-Acts, 111-140. Peabody, MA: Hendrickson.

Evans, C A 1989. Jesus' action in the temple, CBQ 51, 237-70.

Evans, C A 1990. Luke. Peabody, MA: Hendrickson.

Evans, C F 1990. Saint Luke. London: SCM.

Farmer, W R 1964. The synoptic problem. London: SCM.

Fitzmyer, J A 1981-1985. The Gospel according to Luke. New York: Doubleday.

Fox, R L 1986. Pagans and Christians. London: Viking.

Giblin, C H 1985. The destruction of Jerusalem according to Luke's gospel. Rome: PBI.

Goodman, M D 1992. Diaspora reactions to the destruction of the Temple, in Dunn, J D G (ed), Jews and Christians, 27-38. Tübingen: Mohr.

Goulder, M D 1989. Luke - a new paradigm. Sheffield: Sheffield Academic Press.

Grabbe, L L 1991. Judaism from Cyrus to Hadrian. London: SCM.

Grundmann, W 1971. Das Evangelium nach Lukas. Berlin: Evangelische.

Haenchen, E 1971. The Acts of the Apostles. Nashville, TN: Abingdon.

Hengel, M 1983. Between Jesus and Paul. London: SCM.

Hill, C C 1992. Hellenists and Hebrews. Minneapolis, MN: Fortress.

Hoffmann, P 1969. Die Versuchungsgeschichte in der Logienquelle. BZ 13, 207-23.

Hoffmann, P 1982. Studien zur Theologie der Logienquelle. Münster: Aschendorff.

Hollenbach, P J 1979. Social aspects of John the Baptizer's preaching ministry in the context of Palestinian Judaism. ANRW 19, 850-75.

Horsley, R A \& Hanson, J S 1987. Bandits, prophets and messiahs. San Francisco, CA: Harper.

Jacobson, A D 1992. The first gospel. Sonoma, CA: Polebridge.

Jeremias, J 1963. Jerusalem in the time of Jesus. London: SCM.

Jewett, R 1979. Dating Paul's life. London: SCM.

Juel, D A 1983. Luke-Acts: The promise of history. London: SCM.

Kilgallen, J J 1976. The Stephen speech. Rome: PBI.

Klauck, H-J 2003. Magic and paganism in early Christianity. Minneapolis, MN:

Fortress.

Kloppenborg, J S 1989. Q parallels. Sonoma, CA: Polebridge.

Knox, J 1954. Chapters in a life of Paul. London: SCM.

Koester, C R 1989. The dwelling of God. Wilmington. DE: Glazier.

Koet, B J 1989. Five studies on interpretation of Scripture in Luke-Acts. Leuven:

Peeters.

Kraeling, C H 1951. John the Baptist. New York, NY: Scribner.

Lohse, E 1974. s v Xعíp, Хعıропоı́́то5. TDNT 9, 424-37.

Longenecker, B W 1991. Eschatology and the covenant. Sheffield: Sheffield Academic Press.

MacMullen, R 1981. Paganism in the Roman Empire. New Haven, CN: Yale University Press.

Maddox, R 1982. The purpose of Luke-Acts. Edinburgh: Clark. 
Manson, T W 1957. The sayings of Jesus. London: SCM.

Marshall, I H 1978. Commentary on Luke. Grand Rapids, MI: Eerdmans.

Michel, O 1967a. s v voós. TDNT 4, 880-90.

Michel, O 1967b. s v oîkos, oîkı a. TDNT 5, 119-59.

Munck, J 1967. The Acts of the Apostles. New York, NY: Doubleday.

Neusner, J 1983. Formative Judaism. Chico, CA: Scholars.

Nickelsburg, G W E 1981. Jewish literature between the Bible and the Mishnah. London: SCM.

Nolland, J C 1989-1993. Luke. Waco, TX: Word.

O'Toole, R F 1984. The unity of Luke's theology. Wilmington, DE: Glazier.

Pesch, R 1986. Die Apostelgeschichte. Neukirchen-Vluyn: Neukirchener.

Plummer, A 1901. A critical and exegetical commentary on the Gospel according to $S$ Luke. Edinburgh: T\&T Clark.

Reicke, B I 1972. Synoptic prophecies on the destruction of Jerusalem, in Aune, D E (ed), Studies in the New Testament and early Christian literature, 121-134. Leiden: Brill.

Richard, E E 1978. Acts 6:1-8:4. The author's method of composition. Missoula, MT: Scholars.

Robinson, J A T 1976. Redating the New Testament. London: SCM.

Robinson, J M \& al. 2000. The critical edition of Q. Minneapolis, MN: Fortress.

Roloff, J.1981. Die Apostelgeschichte. Göttingen: Vandenhoeck \& Ruprecht.

Sacchi, P 2000. The history of the second temple period. Sheffield: Sheffield Academic Press.

Saldarini, A J 1988. Pharisees, scribes, and Sadducees in Palestinian society. Wilmington, DE: Glazier.

Sanders, E P 1985. Jesus and Judaism. London: SCM.

Sanders, E P 1992. Judaism: practice and belief 63 BCE-66 CE. London: SCM.

Sanders, J T 1987. The Jews in Luke-Acts. London: SCM.

Scharlemann, M H 1968. Stephen: A singular saint. Rome: PBI.

Schneider, G 1985. Das Evangelium nach Lukas. Bonn: Hanstein.

Schneider, G 1980-1982. Die Apostelgeschichte. Freiburg: Herder.

Schulz, S 1972. Die Spruchquelle der Evangelisten. Zürich: Benziger.

Schürer, E et al 1979. The Jewish people in the age of Jesus Christ. Edinburgh: Clark.

Schürmann, H 1982. Das Lukasevangelium. Freiburg: Herder.

Schweizer, E 1966. Concerning the speeches in Acts, in Keck, L E \& Martyn, J L (ed), Studies in Luke-Acts, 208-216. Nashville, TN: Abingdon.

Scobie, C H H 1964. John the Baptist. London: SCM.

Simon, M 1951. Saint Stephen and the Jerusalem temple. JEH 2, 127-42.

Simon, M 1958. St Stephen and the Hellenists in the Jerusalem church. London: Longman.

Smith, J Z 1978. Map is not territory. Leiden: Brill.

Smith, J. Z 1987. To take place. Chicago, IL: University of Chicago Press.

Squires, J T 1993. The plan of God in Luke-Acts. Cambridge: CUP.

Sylva, D D 1987. The meaning and function of Acts 7: 46-50. JBL 106, 261-75.

Taylor, N H 1992. Paul, Antioch and Jerusalem. Sheffield: Sheffield Academic Press. 
Taylor, N H 1996. Palestinian Christianity and the Caligula Crisis. JSNT 61, 101-24; 62, 13-41.

Taylor, N H 1999a. Jerusalem and the temple in early Christian life and teaching. Neotestementica 33, 445-461.

Taylor, N H 1999b. Luke-Acts and the temple, in Verheyden, J (ed), The Unity of Luke-Acts, 409-421. Leuven: Peeters.

Taylor, N H 2001. The temptation of Jesus on the mountain (Mt 4:8-10). JSNT 83, 27-49.

Taylor, N H 2003a. The destruction of Jerusalem and the transmission of the synoptic eschatological discourse. HTS 59, 283-311.

Taylor, N H 2003b. Stephen, the temple, and early Christian eschatology, Revue Biblique 110, 62-85.

Theissen, G 1991. The gospels in context. Edinburgh: Clark.

Tiede, D L 1983. Prophecy and history in Luke-Acts. Philadelphia, PA: Fortress.

Trocmé, E P 1975. The formation of the gospel according to Mark. London: SPCK.

Tuckett, C M 1992. The temptation narrative in $Q$, in van Segbroeck, $F$ et al (ed), The Four Gospels, 479-507. Leuven: Peeters.

Walker, P W L 1996. Jesus and the holy city. Grand Rapids, MI: Eerdmans.

Webb, R L 1991. John the baptizer and prophet. Sheffield: Sheffield Academic Press.

Weinert, F D 1982. Luke, the temple, and Jesus' saying about Jerusalem's abandoned house. CBQ 44, 68-76.

Wilson, S G 1973. The gentiles and the gentile mission in Luke-Acts. Cambridge: CUP.

Wilson, S G 1983. Luke and the Law. Cambridge: CUP. 